\title{
Workforce Management Based On Charity in Muslim Organizations
}

\author{
Zin-Eddine Dadach \\ Assistant Professor \\ Department of Chemical and Petroleum Engineering, \\ Abu Dhabi Men's College \\ Higher Colleges of Technology (HCT) \\ Abu Dhabi (Abu Dhabi), UAE \\ E-mail: zdadach@hct.ac.ae
}

Received: June 06, 2020

Accepted: July 03, 2020

Online Published: July 27, 2020

doi: I0.4628I/ijibm.v4i2.677

URL: https://doi.org/I0.4628I/ijibm.v4i2.677

\begin{abstract}
Islamic literature highlights eight major functions of Islamic HRM; namely HR planning, recruitment, selection, orientation, performance appraisal, training and development, compensations and benefits, and career development. The objective of this paper is to consider the Divine Science of Charity as it applies to organizations as a form of workforce management. Firstly, in order to properly apply the divine laws of charity in any hierarchy, every employee should be allocated to a position correlating to their skill level. In addition, if everyone in the company is willing to please Allah (SWT) by helping personnel under supervision (mu'āmalāt), it will result in minimum friction between employees, meanwhile boosting the morale and engagement of all personnel. This will result in the maximized efficiency of the workflow at each level of the organization. Moreover, the reward for charity-leaders is happiness, which will allow them to create an enjoyable environment in the workplace. For the 2 nd divine law of charity, each member of the company will be able to self-purify their soul and add the workflow as good deeds in the Eternal Path of Charity.
\end{abstract}

Keywords: Workforce Management, Soft Skills, Divine Science of Charity, Mu'āmalāt.

\section{Introduction}

\section{I.I Workforce Management in Organizations}

Organizations are social units of people, including a management structure that determines relationships between different activities and members, which subdivides and assigns roles, responsibilities, and the authority to carry out different tasks. In any company, positions within each level of the hierarchy require the application of both hard and soft skills, and employees are generally selected based on these two categories. Hard skills are mainly the three elements of KSA (Knowledge, Skills and Abilities) that define the maximum theoretical amount of workflow that could be achieved (Reh, 20I9). On the other hand, soft skills (Communication, Teamwork, Adaptability, Problem-Solving, Creativity, Work Ethic, Interpersonal Skills and Time Management) affect the efficiency of interactions between employees (Doyle, 2020). In other words, what is the theoretical percentage of the workflow that soft skills account for? Notably, most companies create a dynamic in which personnel compete against each other for recognition, bonuses, and promotions. Some research studies indicate that competition can motivate employees, encourage them to put in more effort and work harder to achieve better results. Indeed, competition increases physiological and psychological activation, which prepares both body and mind for increased effort and enables higher performance (Steinhage, Cable, \& Wardley, 2017). However, competition can have a negative impact if employees compete against co-workers who have higher skills. During research, data collected from banks, law firms, and technology companies suggests that the way competition makes people feel plays a crucial role in how they try to win. The negative consequences of lagging behind can trigger anxiety and prompt people to resort to mis-selling, fraud, and lying to customers (Steinhage, Cable, \& Wardley, 2017).

Practicing Human Resources Management (HRM) is the lifeblood of an organization because all of the organization's employees' enthusiasm, satisfaction, quality and experience as well as their sense of fair treatment can affect the firm's productivity, customer service, reputation and long-term survival (Chowdhury, Hoque \& Mawla, 20I9). In order to maximize 
the quality of interaction between company personnel and the efficiency of the workflow, workforce management (WFM) facilitates the accurate ranking of employees in the hierarchy according to skill level. This will reduce internal tensions and enable employees to fulfil their full potential. On the other hand, the incorrect ranking of employees could lead to friction in the hierarchy. Traci Moxson elaborates that "it's clear that the time has come for organizations to put substance behind the phrase 'people are our most important asset' and genuinely deliver right skills, right place, right time!" (Moxson, 20I4). Being in the right position in the organization, and the influence of managers on the efficiency of workflow at any level of the hierarchy, depends mainly on how they affect (soft skills) the employees under their supervision. Eight recognized leadership styles are evident in the literature, namely: (a) Democratic, (b) Autocratic, (c) Laissez-faire, (d) Strategic, (e) Transformational, (f) Transactional, (g) Bureaucratic and (h) Servant (Cherry, 2018a; Cherry, 2018b; Becker, 2018; Sendjaya \& Sarros, 2002). In addition to the style of leadership, the personality traits suggested for highly desirable managers are: (a) confidence (b) honesty (c) communication skills (d) empathy (e) optimism (f) encouragement (g) intuition (h) acting as a role model (Top Leadership Qualities of the Holy Prophet Muhammad (PBUH), 2018). For example, it's been widely found that managers who help employees under their supervision to succeed (Figure I) could also make them better leaders (Hopper, 2020).

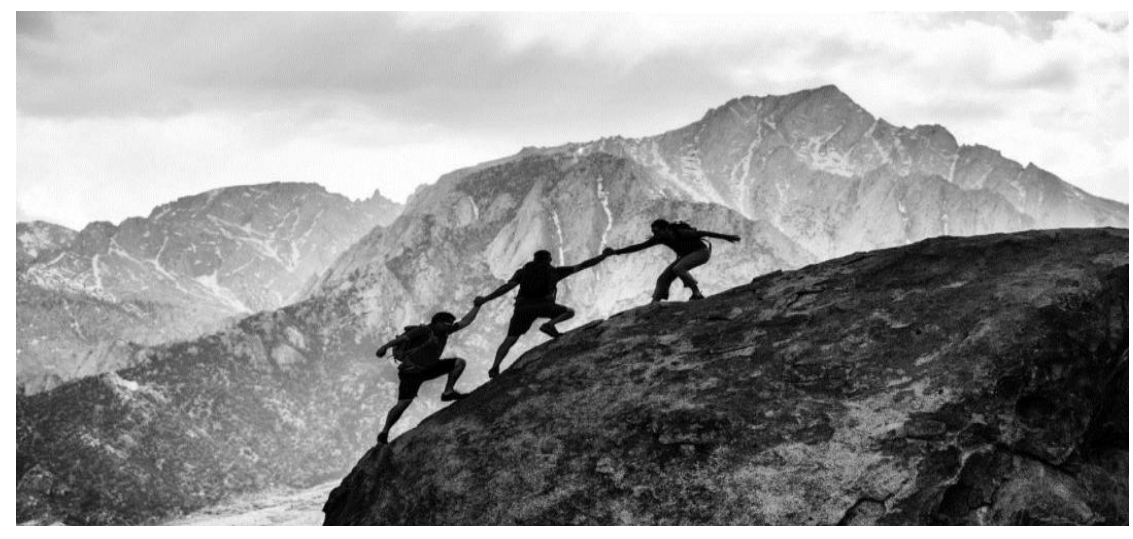

Figure I. Helping Others Make Better Leaders (Elizabeth Hopper, 2020)

Mary Kay Ash reiterates "We need leaders, who add value to the people and the organization they lead; who work for the benefit of others and not just for their own personal gain. Leaders who inspire and motivate, not intimidate and manipulate; who live with people to know their problems in order to solve them and who follow a moral compass that points in the right direction regardless of the trends"(Julian, 2018).

\section{I.2 Islamic View of Managing Human Resources}

From an Islamic perspective, managing human resources meets various challenges, especially in modern organisations. The adoption of Western practices in various aspects of management has caused gaps in justice, trustworthiness, responsibility and other worker values in Muslim countries. The embedding of Islamic principles in human resource management (HRM) can be considered a great solution for treating employees fairly and justly (Osman, Mahphoth, \& Hashim, , 20I4). Since Islam is a complete code of life, Islamic human resource management is the practice that sustains high employee performance based on the guidelines of Quran and Sunnah through human resource planning, recruitment or decruitment, selection, orientation, training, compensation and benefits, performance appraisal, and career development (Shukor , 2018). First of all, Quran and Sunnah refer to honesty and justice in trade, and call for an equitable and fair distribution of wealth in society. In the context of "Islam and Work," light is shed on the obligations of the worker, in particular towards his work and in general towards his employer. The more committed to his religion, the more committed he has to be to his work. Hence, as per the teachings of Islam - by working with more dedication as per the agreed terms of his employment, the employee justifies his earning and livelihood and at the same time stands out as a role model for the believers and non-believers alike (Khan, Farooq, \& Hussain, 2010). Islamic literature highlights eight major functions of Islamic HRM such as HR planning, recruitment, selection, orientation, performance appraisal, training and development, compensations and benefits, and career development (Chowdhury, Hoque, \& Mawla, 2019). However, absence of suitable Islamic guidelines regarding Human Resources Management (HRM) is one of the key challenges in Muslim countries.

Traditional jurisprudence (fiqh) in Islam distinguishes between two principal branches of law, rituals (ibādāt) and social relations (mu'āmalāt). In the same way as we worship Allah (SWT) with our prayers (ibādāt) in mosques, as Muslims we apply this more widely to our social lives, and demonstrate our faith in Him in our places of work by developing a 
trustworthy and sincere environment. (mu'āmalāt). For example, while conducting different HRM practices such as recruitment, selection, training, performance appraisal, and motivation, employees should be fair and take decisions in an unbiased manner (Khan, Farooq, \& Hussain (2010). In respect of the modern world, where employees are treated as per their position and power, Islam teaches equal treatment of employees irrespective of their assigned task. Moreover, the concept of work understood from the Islamic perspective says that one should excel and become successful in life following the ethics of Islam - that is according to the Quran and the sayings of the Prophet (PBUH). Favoritism which is sometimes practiced in modern society is not a part of Islamic culture. Another significant contribution of Islam is in the area of compensation and wages. It prescribes the principle of fair and timely compensation which meets the basic needs of the employee and adds to the standard of living. For today's working individual, many of the hours awake are spent at the workplace, hence it becomes imperative and binding on every Muslim to become an honest, truthful, righteous and dedicated worker. If work is conducted in an ethical manner, he will please Allah - the only aim of any Muslim (Khan, Farooq, \& Hussain, 20I0).

This paper focuses mainly on the impact of soft skills on the efficiency of workflows in organizations in Muslim countries. For this purpose, all soft skills are considered in this investigation as being based on the intention to please Allah (SWT) alone by the willingness to help employees under supervision. In this case, all workflows will be counted as good deeds. Since our soul is eternal, the term "Eternal Path of Charity" is introduced in this paper for the charity of every employ that selfpurifies their soul.

\section{Method: The Divine Science of Charity}

The proposed model is based on the divine science of charity, two Quranic verses and a spiritual interpretation of the movement of water in nature. First, from the Quranic verse "And the heaven He has risen high, and has set up a Balance"; Quran; 55: 7(AlHilali \& Khan, 2000). Allah (SWT) created earth as a sphere and the sun heats equatorial regions more than Polar Regions. As a consequence, some regions of the planet are abundant in energy, while others are deficient. This uneven distribution of solar radiation is responsible for the imbalance and the "gradient of energy" around the planet. Based on this first Quranic verse (55:7), it is understood that Allah (SWT) urges regions rich in energy to give part of this richness as charity to regions poor in energy in order to create balance and harmony in nature. This is described in this study as the Ist divine law of charity of the Divine Science. From the second Quranic verse "And there is not a thing but that with Us are its depositories, and We do not send it down except according to a known measure.";Quran, I5:2I (Al-Hilali \& Khan, 2000). which is described as $2^{\text {nd }}$ divine law of charity of the Divine Science, Allah (SWT) also prescribes the amount of the matter or energy to flow from a rich region to a poor region (Figure 2).

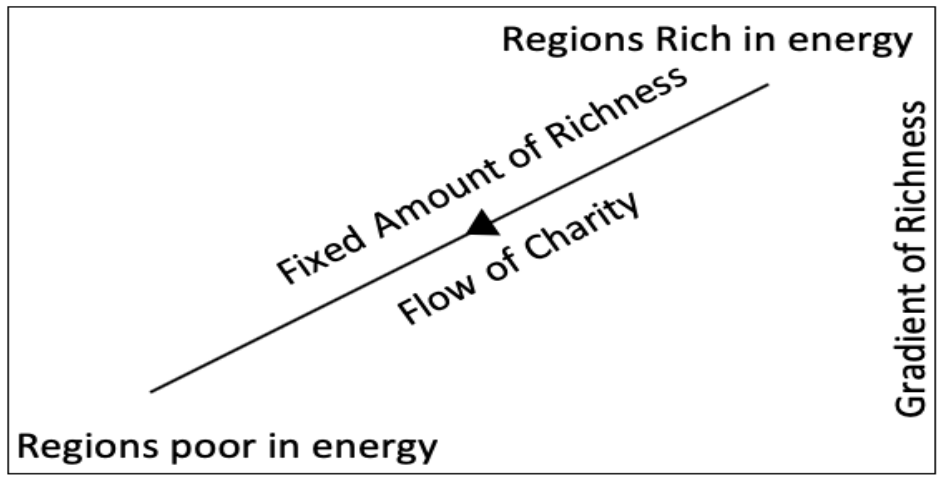

Figure 2. The Divine Science of Charity in Nature (Author's Figure)

\section{Method: Applying the Divine Science of Charity in Workforce Management}

The most important lesson learned is that Allah (SWT) used nature as a universal educator in order to demonstrate that His science is based on charity for the purpose of balance and harmony. Similar to nature, the divine laws of charity for Muslims are also indicated in the Quran. There is therefore complete harmony between the signs of Allah (SWT) in nature, scientifically described by universal laws and His words in the Holy Quran. Based on these facts, the main objective of applying the Divine Science of Charity in workplaces is to give each member of the company the opportunity to worship Allah (SWT) through selfpurification of their soul and the good deeds of the workflow in the Eternal Path of Charity.

\section{I Conditions for Applying the Ist Divine Law of Charity}

"If there were in the heavens and the earth, other gods, besides Allah, there would have been collision in both."; Quran; 21:22 (Al-Hilali \& Khan, 2000). This Quranic verse demonstrates the significance and requirement of unity, in command and 
direction. Therefore, following in the Islamic tradition, this paper proposes the application of the Divine Science of Charity in order to optimize workforce management in organizations. Firstly, identical to the pattern of natural flow, there are also "workflows" and "interactions" between employees at all levels of the hierarchy. In order to enforce the Ist divine law of charity, similar to the "gradient of energy" in nature, there is a need to have a "gradient of skills" in the hierarchy. For this purpose, the selected managers at the top level of the administration should have the most developed expertise and ability in all the needed skills and employees at the lower levels of the hierarchy should have less developed ability and skill to perform the duties.

\subsection{Conditions for Applying the 2nd Divine Law of Charity}

"We raise some of them above others in ranks, so that some may command work from others..." Quran; 43:32 (Al-Hilali \& Khan, 2000). This Quranic verse illustrates the entire attitude and insight of modern management. It highlights, in essence, the creation of appropriate hierarchies and the division of responsibilities subject to individual ability. Therefore, the application of the 2nd Divine Law of Charity can be considered similar to balance and harmony in nature. Personnel with intermediate skills should be allocated to an appropriate rank of the hierarchy to best utilize their skills, and give proper advice, instruction, and guidance to employees under their supervision, thereby creating equity amongst employees of an organization and giving everyone the opportunity to fulfill the divine duties of charity. This exemplifies the saying of The Prophet (PBUH) "Allah loves, when one of you is doing something, that he [or she] does it in the most excellent manner” Al-Qaradawi (I995), which requests Muslims to fulfill the requirements and responsibilities of their role or job to the best of their expertise. All soft skills are considered as being based on the intention to please Allah (SWT) alone in this Islamic model (Ist Divine Law of Charity) by willingness to help employees under supervision. Indeed, research has shown that helping others to become successful will remove the obstacles, excessive bureaucracy, interpersonal conflict, uncertainty and toxic cultures that hinder success (Monarth, 2016). Moreover, a study found that when people engaged in reactive helping (helping when asked), they received more gratitude. In turn, the helpers perceived that they had a greater impact and felt more engaged at work the next day (Tiayon, 2019).

\section{Expected Results of Applying the Divine Science of Charity in Workforce Management}

\section{I Impact on the Efficiency of Workflow}

"O you who believe! Do your duty to Allah and fear Him. And seek the means of approach to Him, and strive hard in His cause so you might be successful."; Quran; 5:35 (Al-Hilali \& Khan, 2000).

Considering the difference in hard skills between a manager and an employee under supervision as the "driving force" at a certain level of the hierarchy, if the manager (Position High) has higher level expertise (Rich skills) than the employee in a lower level position (Position low) and uses all the hard skills to help team members under supervision, it will result in positive values of the efficiency (Equation I) of the workflow at this level of an organization:

\section{Ef ficiency of workflow $\propto\left(\right.$ Rich $_{\text {skills }}-$ Poor $\left._{\text {skills }}\right) /\left(\right.$ Position $_{\text {High }}-$ Position $\left._{\text {low }}\right)>0($ Charity $(\mathrm{I})$}

Moreover, if managers are willing to please only Allah (SWT) during these duties, they can self-purify their soul in the Eternal Path of Charity and the workflow will be counted as charity (Figure 3).

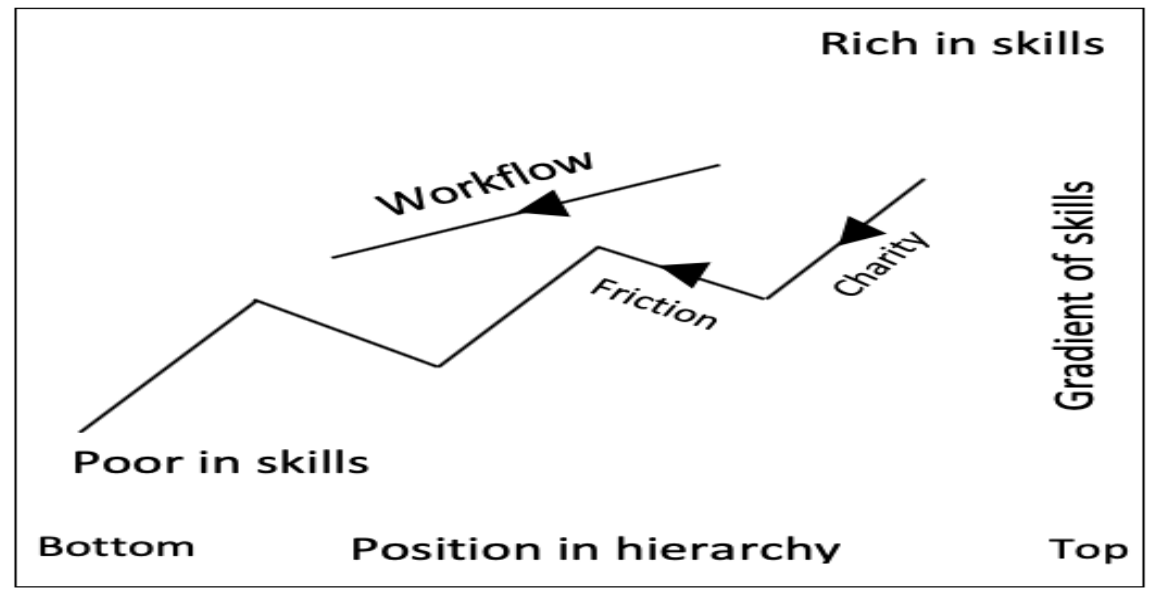

Figure 3. Some employees in the wrong position of the hierarchy (Author's figure) 
However, if employees in positions of authority and more responsibility have to provide leadership to coworkers who are in a lower ranked position but equipped with more developed hard skills, it could result in friction during their interactions (Figure 3). As these managers cannot help other team members, they will not be able to add their workforce activities as good deeds because they cannot fulfill their divine duty of charity. On the contrary, these managers could use fear and humiliation to show their authority. This injustice will cause low morale amongst subordinates and reduce their level of engagement. This friction is translated by the negative values as indicated in equation (2):

\section{Efficiency of workflow $\propto\left(\right.$ Poor $_{\text {skills }}-$ Rich $\left._{\text {skills }}\right) /\left(\right.$ Position $_{\text {High }}-$ Position $\left._{\text {low }}\right)<0($ Friction $)(2)$}

In other words, the negative values of the equation (2), caused by employees incorrectly placed within the ranking system, are similar to adding extra resistance to the workflow. This will potentially affect the efficiency of workflow in the hierarchy and the overall performance of the company in a negative way.

In conclusion, if the divine laws of charity are properly applied to workforce management within organizations, employees will be ranked in a position which aligns with their ability in the hard skills. Moreover, if everyone in the organization is willing to please Allah (SWT) by helping personnel under their supervision, minimum friction will result between employees and the morale and engagement of all personnel will be boosted. As a result, Figure 4 illustrating to workforce management will be similar to figure 2 related to the Divine Science of Charity in nature. Therefore, the efficiency of the workflow at each level of the organization will have the maximum positive values. Additionally, the employees who have received help are more likely to help others in return. Moreover, workplaces with helping cultures see better employee performance. Research also suggests that more helpful workplaces actually perform better; they produce better-quality products and have increased sales (Tiayon, 2019).

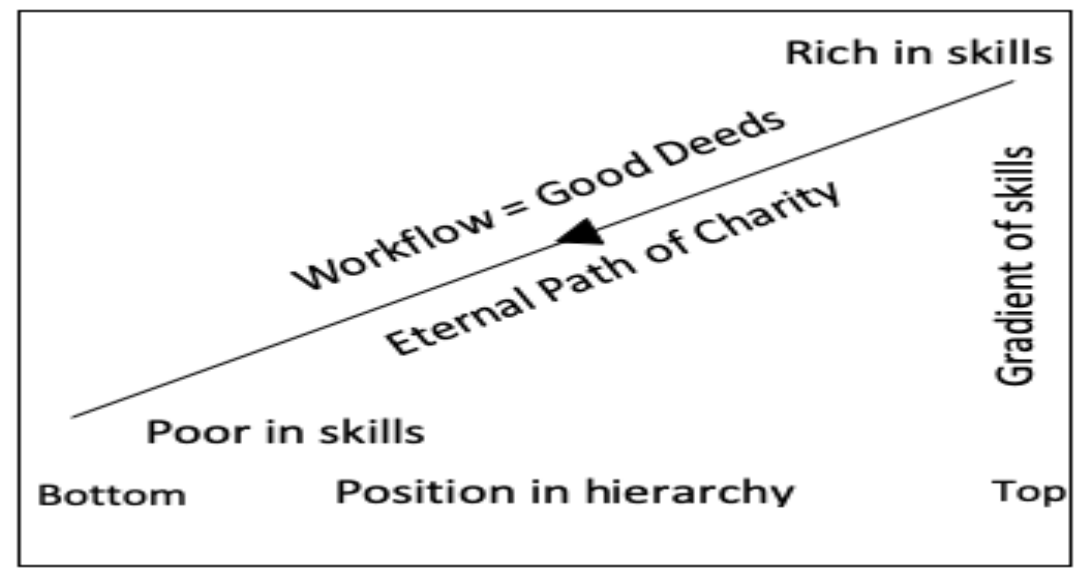

Figure 4. Applying the Divine Science of Charity in Organizations (Author's figure)

\subsection{Impact of Applying the Divine Science of Charity on happiness in workplaces}

Moreover, similar to the abundance of spring after the gestures of charity in nature, the reward for the managers who obey Allah (SWT) and His universal laws of charity is certainly lasting happiness as Allah (SWT) says "As for him who gave out his wealth (for Allah's sake) and abstained (from disobeying Him), and affirmed the Truth of goodness, We shall facilitate for him the Way to Bliss; Quran; 92-5:7 (Al-Hilali \& Khan, 2000). This has been shown in MRI scans which illustrate this "warm-glow effect" in the reward centers of the brain (Dunn, Aknin, \& Norton (2008). According to the Islamic literature, properly helping others within companies should follow this advice:

- Always present a smiling face to people as one of Prophet Muhammad's companions said: "Since the day I accepted Islam, the Messenger of God would never meet me without a smiling face”(Schwartz, 20I8).

- Show kindness to people and transform all your daily actions and activities to acts of charity as Allah (SWT) says "Truly, Allah is full of kindness, the Most Merciful towards mankind.”;Quran; 2:I43 (Al-Hilali \& Khan, 2000).

- Be thankful to Allah (SWT) during happy moments and be patient during times of hardship and pain as Prophet Mohamed (PBUH) said "I am amazed by the believer. If he is granted goodness, he praises Allah and is grateful. If he is afflicted with a calamity, he praises Allah and is patient” (Elias, 20I4).

Finally, each member of a company will be able to self-purify their soul and add the workflow as good deeds in the Eternal Path of Charity. Integrating the Divine Laws of Charity in an organization will result in the highest performance of the 
company due to the smoothest workflow and most enjoyable environment in the workplace.

\section{Discussion and Conclusion}

Islamic literature highlights eight major functions of Islamic HRM, namely; HR planning, recruitment, selection, orientation, performance appraisal, training and development, compensations and benefits, and career development. This paper has focused mainly on the impact of soft skills on the efficiency of workflows in organizations in Muslim countries. To address this objective, this paper was based on the Divine Science of Charity in its application to organizations as a form of workforce management. For this purpose, all soft skills were considered in this investigation as being based on the intention to please Allah (SWT) alone by the willingness to help employees under supervision. Firstly, in order to properly apply the Divine Laws of Charity in any hierarchy, every employee should be allocated to a position which correlates with their skill level. Our study has suggested that if companies properly apply the Divine Laws of Charity by giving each employee an appropriate position, leaders at all levels of the hierarchy can effectively and fully share their knowledge with employees under their supervision. In addition, if everyone in the company has willingness to please Allah (SWT) by helping personnel under their supervision (mu 'āmalāt), the morale and engagement of all personnel is increased with minimized friction between employees. This results in the efficiency of the workflow at each level of the organization being maximized. Due to this practice, the effectiveness of administrative and technical flows can be optimized at all levels of the organization, leading the company towards excellence. Moreover, the reward for the charity-leaders is happiness, which allows them to create a more enjoyable environment in the workplace. Finally, each member of the company can self-purify their soul and add the workflow as good deeds in the Eternal Path of Charity. On a last note, with His Infinite Mercy, Allah (SWT) requires Muslims to worship Him in workplaces by helping others and to count their daily duties as good deeds, thereby giving them the opportunity to self-purify their soul in the Eternal Path of Charity. Finally, Allah (SWT) also reassures us that He is our only provider for all our wealth, including salary as mentioned in the Quran "And no moving creature is there on earth but its provision is due from Allah. And He knows its dwelling place and its deposit. All is in a Clear Book.”; Quran: II:6 (Al-Hilali \& Khan, 2000).

\section{References}

Al-Hilali, M. T., \& Khan, M. M. (2000). Interpretation of the meanings of the Noble Quran by, Darussalam. Al-Qaradawi, Y. (I995). Dawr al-Qiyam wa-al-Akhlaq fi al-Iqtisad al-Islami. Kaherah: Maktabah Wahbah.

Becker, B. (2018). The 7 most common leadership styles \& how to find your own. Hubspot, May. Retrieved from https://blog.hubspot.com/marketing/leadership-styles.

Chowdhury, A. H ., Hoque, N., \& Mawla, M. M. (2019). Human Resource Management from Islamic Perspective, Bangladesh Journal of Islamic Thought, 7(I00), 19-35. Retrieved from https://www.researchgate.net/publication/335758017_Human_Resource_Management_from_Islamic_Perspective

Cherry, K. (2018a). Autocratic Leadership: Key Characteristics, Strengths, and Weaknesses of Autocratic Leadership, Very well mind, October 22, 2018.

Cherry, K. (20I8b). What Is Democratic Leadership? Characteristics, benefits, drawbacks, and famous examples, Very well mind, October 23, 2018.

Doyle, A. (2020). What Are Soft Skills? The Balance careers. Retrieved from https://www.thebalancecareers.com/what-aresoft-skills-2060852

Dunn, E. W., Aknin, L. B., \& Norton, M. I. (2008). Spending money on others promotes happiness. Science, 3I9(5870), I $687-1688$.

Elias, A. A. (2014). Everything Allah decrees is good for the believer in Faith in Allah. Retrieved from https://abuaminaelias.com/everything-decreed-is-good-for-the-believer-both-ease-and-hardship/

Hopper, E. (2020). Helping Others Makes Better Leaders (5 Tips to Grow Others) in Approachable leadership. Retrieved from https://approachableleadership.com/helping-others/

Julian, K. (2018). Great Leadership Quotes for Helping Others Grow in Live it Forward. . Retrieved from https://liveitforward.com/IO-great-leadership-quotes-for-helping-others-grow/

Khan, B., Farooq, A., \& Hussain, Z. (2010). Human resource management: an Islamic perspective. Asia-Pacific Journal of Business Administration.

Monarth, H. (2016). Act Like a Leader: Help Others Succeed. Build Strategic Alliances. Know Yourself. Entrepreneur https://www. entrepreneur. com/article/272725.

Moxson, T. (2014). The Right People, In The Right Place, at The Right Time; ICMI, Published: April $02,20 I 4$. https://www.icmi.com/resources/20I4/the-right-people-in-the-right-place-at-the-right-time

Osman, I., Mahphoth, M. H., \& Hashim, M. J. (20I4). Human resource management from an Islamic perspective: experiences of GLCs. In Proceedings of the International Conference on Science, Technology and Social Sciences (ICSTSS) 2012 (pp. 217-227). Springer, Singapore. 
Quranreading.(2018). Top Leadership Qualities of the Holy Prophet Muhammad (PBUH): Retrieved from http://www.quranreading.com/blog/top-leadership-qualities-of-the-holy-prophet-muhammad-pbuh/

Reh, J. F. (2019). KSA: Using the Knowledge, Skills and Abilities Model. The Balance Careers website, 4.

Schwartz, A. (2018). Even a Smile is Charity: A Life Example in Truth Seeker. Retrieved from https://www.truthseeker.info/oasis-of-faith/even-a-smile-is-charity-a-life-example.

Steinhage, A., Cable, D., \& Wardley, D. (2017). The pros and cons of competition among employees. Harvard Business Review https://hbr. org/2017/03/the-pros-and-cons-of-competition-among-employees.

Sendjaya, S., \& Sarros, J. C. (2002). Servant leadership: Its origin, development, and application in organizations. Journal of Leadership \& Organizational Studies, 9(2), 57-64.

Shukor, S. A. (2018). Business Development in Islamic Perspectives in Entreprenuership, Organisational Behaviour \& Islamic Foundation http://gsmuamalat.usim.edu.my/3I4I-2/

Tiayon, S. B. (2019). When You Should Help Your Coworkers—and When to Think Twice; Greater Good wants to know: Do you think this article will influence your opinions or behavior.

\section{Copyrights}

Copyright for this article is retained by the author(s), with first publication rights granted to the journal. This is an open-access article distributed under the terms and conditions of the Creative Commons Attribution license (http://creativecommons.org/licenses/by/4.0/). 